\title{
The Mediating Role of Firm's Performance on The Relationship between Free Cash Flow and Capital Structure
}

\author{
Asep Risman ${ }^{1}$, Parwoto $^{2}$, Agus Sunarya Sulaeman ${ }^{3}$ \\ 1 lecturer of Universitas Mercu Buana, Jakarta, Indonesia. E-mail: asep.risman@mercubuana.ac.id \\ 2 lecturer of Universitas Mercu Buana, Jakarta, Indonesia. E-mail: parwoto.parwoto@mercubuana.ac.id \\ 3 lecturer of State Finance Polytechnic STAN, Banten - Indonesia. E-mail: asunarya@pknstan.ac.id
}

\begin{abstract}
This study aims to examine the effect of Firm's performance as an intervening in the influence of the free cash flow on the capital structure. As well as the direct effect of Firm's performance and free cash flow on the capital structure. This study uses a path analysis model and polling data from on 22 companies of various industrial subsectors on the Indonesia Stock Exchange (IDX), over a period of 10 years (2009 to 2018). The results show that although free cash flow does not directly affect the capital structure, it is proven that profitability affects the capital structure and can mediate the effect of free cash flow on capital structure. These findings support agency theory, that management prefers to use free cash flow to make investments, so that fluctuations in the free cash flow will affect the financial performance, this condition will ultimately affect the capital structure.
\end{abstract}

Index Terms: Capital Structure, Free Cash Flow, Firm's Performance, Indirect Effect, Leverage, Mediating Variables, Profitability.

Article Received: 10 August 2020, Revised: 25 October 2020, Accepted: 18 November 2020

\section{Introduction}

CAPITAL structure is an important topic in the company's financial management literature (Brealey et.al., 2011), because the combination of capital structure will have a direct effect on the company's financial condition. There have been many studies on the factors that influence the capital structure and are still of interest to researchers all the time. There are many factors that influence the capital structure, including company performance or profitability. Several recent studies on this topic include Khushi et al. (2020). Atseye et al. (2014), Oppong-Boakye et al. (2013), Khalid Alkhatib (2012), Xu (2012), Gill et al. (2011) and Chou and Lee (2010), as well as Karadeniz et al. (2009).

Another factor is free cash flow, this is a new topic in the last decade, many previous studies do not consider free cash flow as a factor that affects the capital structure. Recent studies on this topic include Ulum and Matrodji (2019), Alnawaiseh et al. (2017), Rezaei and Jafari (2015), Rezaei and Jafari (2015), Zurigat et al. (2014), Shah and Jame-Kausar (2012), Shubita and Alsawalhah (2012), Charalambakis and Psychoyios (2012), Qureshi et al. (2012), Amalendu (2012), Khalid Alkhatib (2012).

Apart from previous findings that still show mixed results, this research and most studies in the field of financial management, focus more on the direct relationship between variables. Another point of view as an alternative to the novelty of research that is different from the previous one is how an independent variable will affect the dependent variable if through other variables as a mediating variable, this alternative perspective still gets less attention from researchers. Therefore, one of the objectives of this study is to add new literature as an alternative to the newness of research that is different from previous studies. 
2 Literature Review And Hypothesis Development

\subsection{Capital Structure}

According to Weston and Copeland (1999) capital structure is permanent financing obtained from long-term debt, preferred stock, and own capital. Meanwhile, according to (Siegel and Shim, 1999), the capital structure is the composition of common stock, preferred stock, and various classes like that, retained earnings, and long-term debt maintained by the business entity in funding assets.

The capital structure in this study is proxied by the Debt to Equity Ratio (DER), as the proxies used in the study refer to previous studies including Gibson (2013); Tailab (2014); Sultan \& Adam (2015); Vătavu (2015); Suardi \& Noor (2015); Tifow \& Sayilir (2015).

\section{DER = Total Liabilities $/$ Total Equity}

Capital structure decisions are one of three financial decisions, namely investment decisions, funding decisions and dividend policies (Van Horne and Wachowicz, 1995), financial decisions are corporate strategic policies that have broad implications for the company, therefore capital structure theories are also company theories, since the M\&M theory (Modigliani and Miller, 1958) which explains the relationship between capital structure and firm value and optimal capital structure, then the theory of bankruptcy costs and financial distress (Myers, 1977) and agency costs (Jensen and Meckling, 1976) ), all of these theories are the basics of the trade-off theory.

The trade-off theory asserts that any increase in corporate debt leads to an increase in the risk of bankruptcy, financial distress and agency costs, and will further negatively impact firm value. However, debt is needed for the company's operational activities and investment which will increase the company's profits and ultimately increase the company's value, as well as the benefits of reducing the company's tax burden. From these two sides, an optimal capital structure is needed, an optimal capital structure can be achieved at least by considering the balance of positive and negative impacts of debt, namely between profits (at least in the form of tax advantages) and losses (financial distress and bankruptcy costs).

The optimal capital structure can be achieved if the financing decision considers the factors that influence the capital structure. According to Karadeniz et al. (2009) the factors that affect the capital structure consist of growth opportunities, fixed assets (tangibility), effective tax rates, nondebt tax shields, company size, profitability, free cash flow and commercial trading position (debt between companies). This study will focus on two factors, namely free cash flow and profitability as indicators of company performance.

\subsection{Free Cash Flow}

There are several definitions of free cash flow, according to Jensen (1986) the excess cash flow after fund all projects perusahaan with a net positive present value (NPV). Ross et al. (2010) that free cash flow refers to cash that the firm is free to distribute to creditors and shareholders because it is not needed for working capital or fixed asset investment. Some experts define free cash flow as operating income less taxes, interest and dividends (Wu, 2004; Wang 2010).

Based on these definitions, in this study, the measurement of flow is as follows:

\section{Free cash flow $=$ (operating income - taxes - interest - dividends) / Total assets.}

The relationship between free cash flow and capital structure is described in 2 (two) capital structure theories, namely the trade-off theory and the pecking order theory. Based on the trade-off theory, it shows a positive relationship between free cash flow and the debt ratio, because companies that have large amounts of free cash flow are exposed to lower risk and borrow more easily in the capital market (Benito, 2003; Jensen, 
1986; Stulz, 1990). However, a negative relationship is implied by the pecking order theory, as it requires an increase in internal funds arising from free cash flow as a source, this relationship is supported by the empirical findings of Rezaei and Jafari (2015) and Karadeniz et al. (2009).

Meanwhile, several enpirical findings support the trade-off theory which shows a positive relationship between free cash flow and debt ratios, including Atseye et al. (2014), Qureshi et al. (2012) and Amalendu (2012).

Based on this explanation, the first hypothesis proposed for this study is:

\section{H1: Free cash flow has a positive and significant effect on capital structure.}

\subsection{Firm's Performance}

Firm's performance is defined differently in different fields and perspectives, therefore in general firmlls performance can be seen from financial and non-financial indicators that quantitatively describe the level of achievement of company goals. The firm's performance using financial indicators is based on the firm's financial statements, this approach is also commonly referred to as financial performance which uses the parameters of the firm's ability to generate profits or profitability.

Based on various literatures, there are many parameters proposed to measure profitability and among them are: Return on Assets (ROA), Return on Equity (ROE), Tobin-Q, Profit Margin (PM), Earnings Per Share (EPS), Price- Earnings Ratio (PE), and so on (Al-Matari et al; 2014). In this study, Return on Assets (ROA) will be used as a proxy for Firm's performance or profitability.

The relationship between Firm's performance, in this case profitability, and capital structure, is described in the pecking order theory and the trade-off theory, although these two theories imply a contra effect in the relationship between profitability and capital structure.

According to the pecking order theory, the relationship between profitability and capital structure tends to be negative, companies with high profits outperform companies with low profits in terms of using retained earnings in internal financing. As a result, the pecking order theory shows a negative relationship between profitability and the level of debt (Myers, 1984; Myers and Majluf, 1984). However, empirical studies generally find negative relationships among others Rezaei and Jafari (2015), Shah and Jam-e-Kausar (2012), Shubita and Alsawalhah (2012), Charalambakis and Psychoyios (2012) and Karadeniz et al. (2009)). Meanwhile, Tang and Jang (2007) did not find a significant relationship between profitability and leverage ratios in lodging companies

According to the trade-off theory, the relationship between profitability and capital structure tends to be positive, a high level of profitability leads to a high level of loan capacity. This situation promotes the use of tax-shield, will have a level of trust from prospective creditors, so that the company's profitability has a positive effect on the capital structure, especially the debt ratio, this relationship is supported by the results of previous studies, among others, the findings of Atseye et al. (2014), Oppong-Boakye et al. (2013), Khalid Alkhatib (2012), Xu (2012), Gill et al. (2011) and Chou and Lee (2010) which show a positive relationship between firm profitability and capital structure.

Based on the trade-off theory and enmpirical findings that support the theory, the following hypothesis is formulated:

$\mathrm{H} 2$ : Profitability has a positive and significant effect on capital structure.

\subsection{Free Cash Flow and Company Performance}

Companies that have a lot of free cash flow will be better able to increase revenue. This shows that free cash flow has a positive effect on firm $\|$ s performance. This is in line with previous empirical findings, including the research results of Khushi et al. (2020), Ali et al. (2018), Kamran et al. (2017) and Ambreen \& Aftab (2016) which show a positive relationship with free cash flow on profitability. So that the hypothesis can be formulated as follows:

H3: Free cash flow has a positive and significant 
effect firmlls performance.

\subsection{Indirect Effect of Free Cash Flow on Capital Structure}

Based on theory and supported by empirical findings from previous studies that free cash flow affects profitability and also profitability affects the capital structure, according to Baron and Kenny (1986) that the first path analysis requirement is that the independent variable must significantly influence the mediating variable, then the mediating variable must affect the dependent variable, therefore profitability is possible to become a mediating variable in the indirect relationship of free cash flow and capital structure, so that the hypothesis can be formulated:

H4: Free cash flow has a positive and significant indirect effect on the capital structure through the firm's performance.

\section{Research methodology}

We developed a path analysis for the model in this study, as follows:

Figure 1. Conceptual Model.

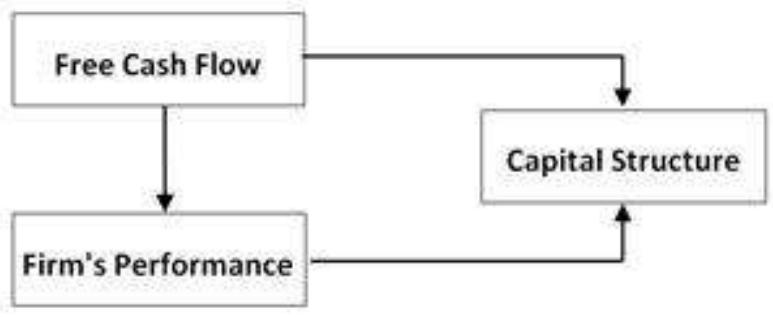

In this model there are two regression equations, the results of the regression equation must meet the requirements of the path analysis method. The regression equation is as follows:

$$
\begin{aligned}
& \text { 1. } \mathrm{DER}=\mathrm{a}+\beta 1 \mathrm{BCF}+\beta 2 \mathrm{ROA}+\mathrm{e} \\
& \text { 2. } \mathrm{ROA}=\mathrm{b}+\beta 1 \mathrm{FCF}+\mathrm{e}
\end{aligned}
$$

Where: the dependent variable is the capital structure (DER), the independent variable is free cash flow (FCF) and the mediating variable is firm performance (ROA).

Selection of the approach used for panel data with the Chow test, Hausman test, and Lagrange multiplier test (LM). While the significant test for the indirect effect of the independent variable on the dependent variable through the mediating variable, we use the regression coefficient comparison.

The population is 22 companies of various industrial sub-sector on the Indonesia Stock Exchange (IDX) in the period 2009 to 2018, all of these populations are used as samples. Then we process the data using the eviews software.

\section{Results and Discussion}

The first thing to do is to calculate the data using the formula for each variable (DER, ROA, FCF) which is tabulated for each variable value. Then because the data used is research data, it is necessary to select a panel data regression approach using the Chow test, Hausman test and Lagrange Multiplier (LM) test, then proceed with model suitability testing and hypothesis testing.

Table 1: Panel Data Regression Model Selection

\begin{tabular}{|l|l|c|l|}
\hline Test & Indicator & Prob & Model \\
\hline Chow & Cross-section & & Fixed \\
Test & Chi-square & 0.0000 & Effect \\
\hline $\begin{array}{l}\text { Hausman } \\
\text { Test }\end{array}$ & $\begin{array}{l}\text { Cross-section } \\
\text { random }\end{array}$ & 0.0342 & $\begin{array}{l}\text { Fixed } \\
\text { Effect }\end{array}$ \\
\hline
\end{tabular}

Source: Output of Eviews

Lagrange Multiplier (LM) testing does not need to be done because the results of the Chow test and the Hausman test show that the appropriate model is the fixed effect model (FEM), while the LM test is used to select the appropriate model between the fixed effect model or the random effect model.

Based on the results of the Chow test, Hausman test and Lagrange Multiplier (LM) test, the fixed effect approach is selected, the regression equation is as follows: 
1. $\mathrm{DER}=1.18180+0.24364 \mathrm{FCF}-5.24256$

ROA 2.ROA $=0.046152-1.853205 \mathrm{FCF}$.

Based on the data from the regression output of eviews, it can be summarized as in the following table:

Table 2: Summary of Fixed Effect Model Regression Estimates

\begin{tabular}{|l|c|c|}
\hline Variable & Coefficient & p-value \\
\hline FCF & 0,243639 & 0,2129 \\
\hline ROA & -5.245260 & 0,0004 \\
\hline
\end{tabular}

The probability value for the free cash flow variable $(\mathrm{FCF})$ is 0.0229 . This is above 0.05 , so the first hypothesis (H.1) is not fulfilled or Free Cash Flow (FCF) does not affect the capital structure (DER). This finding is different from the theory that free cash flow is the amount of cash flow a company can use, one of which is to pay debt (Kieso and Weygandt, 2002; Gitman, 2006; Fleming et al. 2005; Griffin et al. 2010). The results of this study differ or do not support several other empirical findings that show significant results that free cash flow affects the capital structure, including the results of research by Rezaei and Jafari (2015) and Karadeniz et al (2009) which show a negative relationship, on the contrary the results of the study Alnawaiseh et al. (2017) Zurigat et al. (2014) Qureshi et al. (2012), Amalendu (2012) and Khalid Alkhatib (2012) who show a positive relationship. This difference in findings was possible due to the different use of proxies, data and study time periods, in addition to differences in country conditions related to the sample.

The regression coefficient of the ROA variable is -5.245260 , this means that form's performance has a negative effect on the capital structure (DER) of -5.245260 capital structure units (DER). The probability value for the company performance variable (ROA) is 0.0004 or below 0.05 .
Then the second hypothesis (H.2) is fulfilled or significant, that company performance affects the capital structure (DER). This finding is consistent with the pecking order theory which states that companies with high levels of profitability have low levels of debt, because companies with high profitability have excess internal sources of funds so that they will reduce dependence on outside capital. The results of this study support previous empirical findings including the findings of Ulum and Matrodji (2019), Rezaei and Jafari (2015), Shah and Jam-e-Kausar (2012), Shubita and Alsawalhah (2012), Charalambakis and Psychoyios (2012), and Karadeniz et al. (2009) which shows that profitability has a negative effect on capital structure.

However, these findings are different from the empirical findings of previous studies, including the results of Atseye et al. (2014), OppongBoakye et al. (2013), Khalid Alkhatib (2012). Xu (2012), Gill et al. (2011) and Chou and Lee

(2010) which show that profitability has a positive effect on capital structure. This difference is possible due to differences in the use of proxies, both proxies for profitability and capital structure or leverage, as well as differences in the study period, data or countries related to the sample.

Table 3:Summary of Fixed Effect Regression s

\begin{tabular}{|l|l|l|l|}
\hline \multicolumn{2}{|c|}{ Variable } & \multirow{2}{*}{ Coefficient } & \multirow{2}{*}{ P-Value } \\
\cline { 1 - 2 } Independen & Dependent & & \\
\hline ROA & DER & 5.245260 & 0,0004 \\
\hline FCF & ROA & 1.853205 & 0.0464 \\
\hline
\end{tabular}

Based on table 3, that the effect of ROA on DER is -5.245260; the effect of FCF on ROA is 1.853205. then the indirect effect of FCF on DER through ROA is $(\rho 2):-5.245260 \times-1.853205=$ 9.720542058 .

Meanwhile, based on Table 2, the direct effect of free cash flow on the capital structure is $(\rho 1)$ : 0.243639 , so that:

$$
\rho 1(0.243639)<\rho 2(-9.720542058)
$$


So the direct effect of FCF on DER is smaller than the indirect effect through ROA. Thus the fourth hypothesis (H4) is proven or significant, it can be concluded that there is an indirect effect of free cash flow on capital structure through profitability.

These findings indicate that changes in the amount of free cash flow owned by the company will affect the capital structure with a change in profitability first. This is because changes in free cash flow owned by the company will increase or decrease the company's income (return). However, seen from the negative effect of cash flow on company profitability, the increase in free cash flow is used in company activities that can reduce income (return) or increase assets.

These findings support firm theory, particularly agency theory. According to agency theory, managers will prefer to use free cash flow to invest in this case fixed assets, so that fluctuations in free cash flow will affect the company's financial performance, this condition will ultimately affect the capital structure.

\section{Conclusion}

The management of companies in various industry subsectors that are listed on the Indonesia Stock Exchange (IDX), do not use the company's free cash flow to pay off company debt or for dividends. This is evidenced by the absence of the effect of free cash flow on the capital structure proxied by the Debt to Equity Ratio (DER). If management tends to use free cash flow for dividends, then of course the relationship of the free cash flow variable to DER is negative and significant, because the use of free cash flow for dividends will encourage an increase in the company's stock price (equity), but this is not proven.

Companies tend to allocate free cash flow for investment by buying assets that do not generate additional income (return), this is evidenced by an increase in free cash flow that will reduce company performance (profitability).
Increasing performance (profitability) will encourage positive expectations of investors on share prices, thereby increasing the company's share price or changing the capital structure. This finding is consistent with the pecking order theory that companies with high performance will have low debt, because companies with high profitability will have sufficient internal sources of funds so they do not require outside capital.

Fluctuations in free cash flow will affect the capital structure with a change in profitability first. Management prefers to use free cash flow to invest in this case fixed assets, so that fluctuations in the company's free cash flow will affect the company's financial performance, this condition will ultimately affect the capital structure.

\section{References}

[1] Ahmed, Waseque \& Hasan, Md \& Hoque, Aminul \& Jahangir Alam, Mohammad. (2018). Impact of Free Cash Flow On Profitability: An Empirical Study On Pharmaceutical Company.

[2] Ali, U., Ormal, L., \& Ahmad, F. (2018, January). Impact of Free Cash Flow on Profitability of the Firms in Automobile Sector of Germany. Journal of Economics and Management Sciences, 1(1).

[3] Alnawaiseh, Mahmoud \& Alomari, R.M. \& AlRawashdeh, F. \& Alnawaiseh, M.B.. (2017). The effect of free cash flow on the companies' financial polices: Evidence from Jordan. International Journal of Economic Research. 14. $1-9$.

[4] Amalendu Bhunia (2012). Leverage Impact on Firms Investment Decision: A Case Study of Indian Pharmaceutical Companies. International Journal of Contemporary Business Studies, 3, 1, 35-45.

[5] Ambreen, S., \& Aftab, J. (2016), October). Impact of Free Cash Flow on Profitability of Firms Listed in Karachi Stock Exchange. EuroAsian Journal of Economics and Finance, 4(4), 113-122. 
[6] Al-Matari, Ebrahim \& Al-Swidi, Abdullah \& Hanim, Faudziah. (2014). The Measurements of Firm Performance's Dimensions. Asian Journal of

Finance \& Accounting. 6. 24. 10.5296/ajfa.v6i1.4761.

[7] Baron, R. M. and D. A. Kenny, 1986, The moderator-mediator variable distinction in social psychological research: Conceptual, strategic, and statistical considerations, Journal of personality and social psychology, 51(6): 1173.

[8] Brealey, R. A., Myers, S. C., \& Allen, F. (2011). Principles of Corporate Finance 10th ed. 2. New York (US): McGraw-Hill

[9] Budiman, Surya; Harnovinsah, Harnovinsah (2016). Analysis of the Influence of Cash Flow, Leverage, Growth Rate, Company Size, and Profitability on Dividend Policy (Study on Manufacturing Industry Listed on the Indonesian Stock Exchange 2011-2013 Period). TEKUN: Journal of Accounting and Business Studies, [S.1.], v. 7, n. 1 .

[10] Buus, Tomáš. (2015). A general free cash flow theory of capital structure. Journal of Business Economics and Management. 16. 10.3846/16111699.2013.770787.

[11] Atseye, F.A., Obim, N.E., Awara F.E. (2014), Determinants of fnancial structure: Evidence from Nigerian quoted frms. Research Journal of Finance and Accounting, 5(16), 53-66.

[12] Cardoso, F. T., Martinez, A. L., \& Teixeira, A. J. C. (2014). Free Cash Flow and Earnings Management in Brazil: The Negative Side of Financial Slack. Global Journal of Management and Business Research: D Accounting and Auditing, 14(1).

[13] Charalambakis, E.C. and Psychoyios, D., 2012. What do we know about capital structure? Revisiting the impact of debt ratios on some firmspecific factors. Applied Financial Economics, 22(20), pp.1727-1742.

[14] Chou, S.R. and Lee, C.H., 2010. The Research on the Effects of capital Structure on Firm Performance and Evidence from the Nonfinancial Industry of Taiwan 50 and Taiwan Midcap 100 from 1987 to 2007. Journal of Statistics and Management Systems, 13(5), pp.1069-1078.
[15] Chung, R., Firth, M., Kim, J. B. (2005). FCF agency costs, earnings management and investor monitoring. Corporate Ownership and Control, 2(4), 51-61.

[16] Fleming, G., Heaney, R., \& McCosker, R. (2005), Agency costs and ownership structure in Australia. Pacific-Basin Finance Journal, Issue

[17] Gill, Amarjit, Nahum Biger, Neil Mathur, (2011). The effect of capital structure on profitability: Evidence from the United Statesl. International Journal of Management, Vol. 28, No. 4, Part 1, pp. 3-15

[18] Gitman, L. J. (2006). Principle of Managerial Finance. New York: Addison Wesley

[19] Griffin Paul, Lont David, Sun Yuan., (2010), Agency Problems and Audit Fees Further Tests of the Free Cash Flow Hypothesis. Accounting \& Finance, Vol. 50, Issue 2, pp. 321-350.

[20] Hau, L. L. (2017, April). Free Cash Flow and Firm Performance: Evidence from Sectoral Levels for Vietnamese Listed Firms. International Journal of Advanced Engineering, Management and Science, 3(4).

[21] Hong, Z., Shuting, Y., \& Meng, Z. (2012). Relationship between Free Cash Flow and Financial Performance Evidence from the Listed Real Estate Companies in China. IPCSIT, 36. (n.d.).

[22] Jensen, M.C. (1986). Agency Costs of Free Cash Flow, Corporate Finance, and Takeovers. American Economic Review, Vol. 76, No. 2, pp. 323-329.

[23] Jensen, M.C. and Meckling, W.H. (1976) Theory of the Firm: Managerial Behavior, Agency Costs and Ownership Structure. Journal of Financial Economics, 3, 305-360

[24] Kamran, M., Zhao, Z., Ambreen, S. (2017). Free Cash Flow Impact on Firm's Profitability: An Empirical Indication of Firms listed in KSE, Pakistan. European Online Journal of Natural and Social Sciences, Česká Republika, 6, mar. 2017

[25] Karadeniz, E., Kandir, S.Y., Balcilar, M, and Onal, Y.B., (2009), Determinants of capital structure: evidence from Turkish Lodging Companies, International Journal of Contemporary Hospitality Management Vol.21, No.05, pp. 594-609. 
[26] Maria Khushi, Sajid Mohy uldin,Mohammed Ali Bait Ali Sulaim (2020), Effects of Profitability Measures on Free Cash Flow; Evidence From Pakistan Stock Exchange, International Journal off Scientific \& Technology Research Volume 9, Issue 02.

[27] Oppong-Boakye, P.K. Appiah, K.O. and Afolabi, J.K., 2013. Determinants of Capital Structure: Evidence from Ghanaian Firms. Research Journal of Finance and Accounting, 4(4), pp.44-52.

[28] Qureshi, M.A., Imdadullah, M., Ahsan, T. (2012). What determines leverage in Pakistan? A panel data analysis. African Journal of Business Management, 6, 3, 978-985.

[29] Razaei, Mojtaba and Jafari, Seyedeh, Mahbobeh (2015), Identifying the Relationship between Financial Leverage and Cash Flows of the Companies Listed in Tehran Stock Exchange, Indian Journal of Science and Technology, Vol. 8, No. 27.

[30] Siegel, Joel G dan Jae K. Shim yang diterjemahkan oleh Moh Kurdi. Kamus Istilah Akuntansi. Jakarta : PT Elex Media Komputindo.1999.

[31] Shah, S.Z.A. Jam-e-Kausar, 2012. Determinants of capital structure of leasing companies in Pakistan. Applied Financial Economics, 22(22), pp.1841-1853.

[32] Shubita, M.F. and Alsawalhah, J.M., 2012. The Relationship between capital structure and profitability. International Journal of Business and Social Science, 3(16), pp.104-112

[33] Tang, C.H. and Jang, S.S. (2007), -Revisit to the determinants of capital structure: a comparison between lodging firms and software firms $\|$, International Journal of Hospitality Management, Vol. 26 No. 1, pp. 175-87

[34] Thangjam, R., \& Mahendra, G. (2015, August). Analysis of Relationship between Profitability anf Free Cash Flows to Firms. International Journal in Management and Social Science, 3(8).

[35] Thomas, B. (2000). The Free Cash Flow
Hypothesis for Sales Growth and Firm Performance. Strategic Management Journal.

[36] Ulum, Muhammad and Mustafa, Matrodji, (2019), The Effect of Profitability, Free Cash Flow, Company Growth and Company Size on Debt Policy of Food and Beverage Subsectors Registered in Indonesia Stock Exchange Period 2013-2017, International Journal of Innovative Science and Research Technology, Volume 4, Issue 12.

[37] Wang, Goerge Yungchih. (2010). The Impact of Free Cash Flow and Agency Cost on Firm Performance. Journal Service Science \& Management, 3, 408-418.

[38] Weston, J. Fred dan Copeland. 1999. Manajemen Keuangan. Jilid 2. Terjemahan oleh Jaka Wasana dan Krisbandono. Jakarta: Kina Rupa Aksara.

[39] Xu, J., 2012. Profitability and capital structure: Evidence from import penetration. Journal of Financial Economics, 106(2), pp.427-446.

[40] Zurigat, Zaid, I.S, Iaad, Sartawi, Mustafa, Aleassa, Hasan (2014), Empirical Investigation of Free Cash Flow Hypothesis: Evidence from Jordanian Capital Market, International Business Research, Vol. 7, No. 3, pp. 137- 148 